\title{
Select bibliography of primary sources
}

\section{Archival collections}

British Beer \& Pub Association

Précis of Newspapers

Eldridge, Pope \& Co.

Advertisements

Glasgow University Archives Services

Advertisements

Greenall, Whitley \& Co.

Magee, Marshall \& Co.: Photographs

Heineken UK archives

Advertisements

Courage, Barclay \& Simonds Records

London Metropolitan Archives

Courage, Barclay \& Simonds: Minutes of the Board of Directors

National Federation of Licensed Victuallers: Executive Committee Minute Book

London School of Economics and Political Science

New Survey of London Archives

Merseyside Record Office

Peter Walker \& Son

National Brewery Centre, Burton on Trent

Advertisements

National Repository

Liquor Traffic Central Control Board Archives

Northamptonshire Record Office

Northamptonshire Brewers' Association

Northamptonshire Brewing Company

Staffordshire Record Office

Advertisements

Shropshire Wholesale Brewers' Association

University of Sussex

Mass-Observation Archives

University of Warwick Library, Modern Records Centre

Brewers' Society Archives 
Whitbread Archive

Press Advertisements

Sydney Nevile Papers

\section{Newspapers}

Architect \& Building News

Architects' Journal

Bartender

Brewer \& Wine Merchant

Brewers' Guardian

Brewers' Journal

Brewing Trade Review

Builder

Building

Caterer \& Hotel Keeper Gazette

Christian World

Daily Express

Diva

Economist

Evening Standard (London)

Fellowship of Freedom and Reform

Financial Times

Flavour: The Magazine of Bar Professionals

Glass: The Publican Newspaper Wine Magazine

Guardian

Hotel

Hotel \& Catering Management

Hotel \& Catering Weekly Hotel Review

Indoors: The Trust House Review

Kentish Mercury

Labour Woman

Licensed Victuallers' Gazette

Licensee and Morning Advertiser

Licensing World

Luncheon \& Tea Room

A Monthly Bulletin

Morning Advertiser

Morning Post

New Statesman

New York Times

Pubchef

Pub Leader

Publican

Publican Newspaper

Sussex Daily News 
Temperance Record

3Sixty

The Times

Town \& City Magazine

Tribune

True Temperance Quarterly

Which?

Wine and Spirit Trade Review

Yorkshire Evening News

Yorkshire Herald

\section{House magazines of breweries and pubcos}

Adventure (Allied Domecq)

Advertising Monthly (McEwan \& Company)

Anchor Magazine (Barclay, Perkins \& Co.)

Argosy (Allied Breweries)

Barclay's Magazine (Barclay, Perkins \& Co.)

Bass Brewers (Bass Charrington)

Bass Brewers News (Bass Charrington)

Beer and Skittles (Watney, Combe \& Reid)

Brewery Record (Henty \& Constable)

Butler's (William Butler \& Co.)

Courage News (Courage \& Co.)

Deerstalker (Mitchells \& Butlers)

Golden Cockerel (Courage \& Co.)

Guinness Time (Arthur Guinness \& Co.)

Hand in Hand (Watney, Combe \& Reid)

House of Whitbread (Whitbread \& Co.)

Huntsman (Allied Domecq)

Ind Coope News (Ind, Coope \& Co.)

Malster (Drybrough's Brewery)

Malt \& Hops (John Davenports Brewery)

Mash Tun (Ushers Brewery)

Mine Host (Ind Coope)

The News (Tennent Caledonian Breweries)

Red Hand (Watney, Combe, Reid \& Co.)

Runcorn Newsletter (Bass's Runcorn Brewery)

Staff News (Courage, Barclay \& Simonds, Ltd)

Tennent's Times (Tennent Caledonian Breweries)

Things That Affect Us (Vaux Breweries)

Toby Jug (Tennent Caledonian Breweries)

Truman Times (Truman, Hanbury \& Buxton)

Truman Topics (Truman, Hanbury \& Buxton)

Wetherspoon News (J. D. Wetherspoon \& Co.)

Whitbread's Magazine (Whitbread \& Co.) 


\section{Reference}

'Bars - A Glossary', The Times (Beer in Britain Supplement), 29 April 1958.

Gutzke, David W., Alcohol in the British Isles from Roman Times to 1996: An Annotated Bibliography, Westport, Connecticut: Greenwood Press, 1996.

Kelley's Directories

London's Yellow Pages

McWhirter, Kathryn, The Good Wine Bar Guide, 1986, London: Consumers' Association, 1985.

Post Office Directories of London

Ronay, Egon, Pub and Tourist Sights in Britain, 1973, London: British Tourist Authority, 1973.

\section{Marketing and public opinion surveys}

Acumen Marketing Group, A Report on the British Market for Food in Pubs and Wine Bars, March 1978.

Bradley, Michael, and Fenwick, David, Public Attitudes to Liquor Licensing Laws in Great Britain: An Enquiry Carried Out in October-November, 1970 by OPCS Social Survey Division on Behalf of the Home Office and the Scottish Home and Health Department, 1974.

Breeze, Elizabeth, Women and Drinking: An Enquiry Carried Out on Behalf of the Department of Health and Social Security, 1985.

British Institute of Public Opinion, Survey of Drinking Habits, 1939.

British Market Research Bureau, Licensed Premises: Report of an Attitude Survey, August 1960.

Daily Herald Readers and the Market for Beer and Stout, Aug. 1960.

Gallup, George H., The Gallup International Public Opinion Polls: Great Britain, 1937-75, 2 vols, New York: Random House, 1976.

Interscan, Attitude Survey on Pub Going Habits and Brewery Control and Ownership of Public Houses, Aug. 1970.

IPC Marketing, The UK Beer Market, September, 1977.

Lader, D., and Goddard, E., Omnibus Survey Report No. 31. Drinking: Adult' Behaviour and Knowledge in 2006: A Report Using the ONS Omnibus Survey Produced by the Office for National Statistics on Behalf of the Information Centre for Health and Social Care, London: Office of National Statistics, 2006.

The Lager Market in Scotland, Public Attitude Surveys, June 1967.

Market Information Services, The Problem of Declining Beer Consumption: A Memorandum Prepared for Messrs. Gee \& Partners on Behalf of the Brewers' Society, March 1950.

Market Information Services, What People Think about Public Houses: The Results of a Large-Scale Sample Survey Carried Out among the Adult Population of England and Wales during November, 1949.

Market Opinion Research International, Attitudes to the British Brewing Industry, 1973.

Market Opinion Research International, Attitudes to the British Brewing Industry, 1975. 
Market Opinion Research International, Attitudes to the British Brewing Industry, 1981.

Market and Opinion Research International, Public Attitudes to Pubs and Leisure, June 1984.

Market and Opinion Research International, Public Attitudes to Pubs and Leisure, 1988.

Mass-Observation, A Report on Drinking Habits, Aug. 1948

Mass-Observation, A Survey of Drinking Habits, 1949.

Mintel, Pub Visiting, Leisure Intelligence, November, 2009.

Odhams Press Survey, 1960.

S. H. Benson, The Brewers' Society 1957 Advertising Campaign Market Research Charts, July, 1956.

S. H. Benson, A Summary Report on Attitudes towards Public Houses and Drinking Habits, February, 1958.

S. H. Benson, A Test on the Use of the Words 'Pub' and 'Social', London, Nov. 1959.

Wilson, Paul, Drinking in England and Wales: An Enquiry Carried Out on Behalf of the Department of Health and Social Security, 1980.

\section{Parliamentary papers and official publications}

Alcohol: Its Action on the Human Organism, London: H.M. Stationery Office, 1918.

Evidence of the Interdepartmental Committee on Physical Deterioration, 1904, 32, Cd 2210.

Evidence of the Royal Commission on Alien Immigration, 1902-3, 9, Cd 1742.

Evidence of the Royal Commission on Licensing, 1929-31.

Evidence of the Royal Commission on Liquor Licensing Laws, 1897, 34, C 8355-6; 1898, 36, C 8694.

Evidence of the Select Committee of the House of Lords on Intemperance, 1877, 11 (171, 271, 418).

Evidence of the Select Committee on Sales of Liquors on Sunday Bill, 1868, 14 (402).

National Board for Prices and Incomes, Report No. 13: Costs, Prices and Profits in the Brewing Industry, 1966, Cmnd 2965, 1966-7.

Report of the Central Control Board (Liquor Traffic) Appointed under the Defence of the Realm (Amendment) (No. 3) Act: Second, 1916, 12, Cd 8243; Third, 1917-18, 15, Cd 8558.

Report of the Committee on Amenities and Welfare Conditions in Three Women's Services, 1942, Cmd 6384.

Report of the Inter-Departmental Committee on Physical Deterioration, 1904, 32, Cd 2175. Report of the Monopolies and Mergers Commission on the Supply of Beer for Retail Sale in the UK, Cm 651, 1989.

Report of the Proceedings of the Monopolies and Mergers Commission on the Proposed Merger between Scottish \& Newcastle Breweries PLC and Matthew Brown PLC, Cmnd 9645, 1985.

Return of Women and Children in Public-houses: Information Obtained from Certain Police Forces as to the Frequenting of Public-houses by Women and Children, 1908, Cd 3813. 


\section{Oral history interviews}

Aitken, Stuart, former Sales Director with Whitbread Beer Company, 4 Aug. 2000. Avis, Tony, former executive with Bass Charrington, 26-27 July 1997, Ilkley, West Yorkshire.

Hyde, Neal, former chairman of Hydes' Anvil Brewery, 15 Aug. 1998, Altrincham, Cheshire. 